\title{
Theology And the Gospel of JohN
}

\section{Book Title:}

The Gospel of John and Christian theology

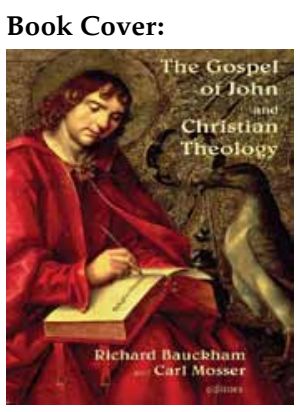

Authors:

Richard Bauckham

Carl Mosser

ISBN:

$978-0-8028-2717-3$

\section{Publisher:}

Eerdmans, Michigan, 2008,

pp. xxiv, 404, US\$32.00*

*Book price at time of Review

Review Title:

Theology and the Gospel

of John

\section{Reviewer:}

Dirk G. van der Merwe ${ }^{1}$

\section{Affiliation:}

${ }^{1}$ Department New

Testament and Early

Christian Studies,

University of South Africa,

South Africa

email:

vdmerdg@unisa.ac.za

\section{Postal address:}

Department New

Testament and Early

Christian Studies,

University of South Africa,

PO Box 392, Pretoria 0003 ,

South Africa

How to cite this book:

Van der Merwe, D.G., 2010,

'Theology and the Gospel

of John', HTS Teologiese

Studies/Theological Studies

66(1), Art. \#981, 2 pages.

DOI: 10.4102/hts.v66i1.98

\section{This review is available} at:

http://www.hts.org.za

(C) 2010. The Authors. Licensee: OpenJournals Publishing. This work is licensed under the Creative Commons Attribution License.
The Gospel of John and Christian Theology is a significant volume which features a collection of essays on numerous topics ranging from the historical assessment of the Fourth Gospel, through to high-octane theological questions. It is edited by the prolific Richard Bauckham and Carl Mosser. This collection of essays was originally presented at the first St. Andrews Conference on Scripture and Theology in 2003 on the very same topic, namely: The Gospel of John and Christian Theology.

The range of contributors is significant and is representative of the various sub-disciplines within the discipline of theology. Younger scholars have been given a voice, in addition to the voices of the more established group being heard (e.g. Martin Hengel, Rowan Williams and Richard Bauckham himself). The essays themselves are thought-provoking and worthy of praise, even if the reader does not necessarily agree with the methodology or conclusions.

In the introduction Richard Bauckham explains that '(t)he aim was to bring biblical scholars and systematic theologians together in conversation about a biblical text that has played a formative role in Christian theology through the centuries' $[p . x]$. He rightly notes the divide that exists between biblical studies and systematic theology and says that this conference and these papers were a means to bridge the gap 'by entering a conversation fruitful to both' [pp. x-xi]. The plan with the conference was to address a number of key issues that normally arise when Christian theologians read the Gospel of John today.

If the aim of this conference was for these two groups of scholars to be involved in conversation with one another, then we shall have to put these essays to the test and raise the question, 'What is meant by conversation'? Unfortunately, this has not been spelled out. In my opinion, specific themes should be decided on and be investigated from both biblical and systematic perspectives. Alternatively, the reading of a paper be followed by a second paper which acts as an evaluation of, or reply to the first paper. This would constitute an 'engagement' between the two disciplines. Unfortunately, such engagement did not happen consistently. In some cases the topic of an essay is linked with the topic of the section, but not with the other topics in the section. Two essays hat are closely connected are: Judith Lieu's 'Anti-Judaism, the Jews and the Worlds of the Fourth Gospel' is a direct response to Stephen Motyer's 'Bridging the gap: How might the Fourth Gospel help us cope with the legacy of Christianity's exclusive claim over against Judaism?' (see p. 169). It is at this juncture that genuine dialogue takes place. My contention is that the book itself succeeded partially in fostering the dialogue that was intended. One should bear in mind that this volume is just the beginning of this new conversation, which can only be enriched by experimentation.

The volume is divided into seven sections. Each section contains essays by biblical scholars and systematic theologians. Unfortunately, the intended conversation was only peripheral. In the two essays in the first section of the volume (John and our pluralist context) some form of conversation is achieved. Each essay confronts one of the difficulties many readers of John have in our contemporary society context with the Gospel. Stephen Barton and Miroslav Volf both challenge the appropriateness of the term 'dualism', distinguishing between different kinds of dualism and preferring to speak of certain carefully specified conceptual dualities in the Gospel of John.

An important aspect pertaining to the theological interpretation of this Gospel is the history of its interpretation. In the second section (Those who read John before us) Jeffrey Bingham shows how the Gospel supported and shaped a key element of Irenaeus's doctrine of God: the divine aseity, or selfsufficiency. Rowan Williams's essay finds a continuity of theological interpretation in the century of Anglican interpretation of John that runs from Bishop B.F. Westcott's English commentary (1882) to Bishop Robinson's The priority of John (1984). Todd Larsson's essay highlights the disagreement between modern Johannine scholars with regard to the issue of whether the revelation of the divine glory in Jesus' exaltation takes place in spite of his human death, or actually by way of his humiliating suffering and death. Due to the divergent topics covered no conversation unfortunately takes place in this section.

It is widely agreed that, owing to the differences between John and the Synoptic Gospels, the issue of historic reliability of the Gospels takes a special or different form in the case of John. In the third section under the heading, 'History and Testimony in John', Stephan Evans points out that the Gospel of John actually presents itself as testimony, the testimony of the Beloved Disciple and it is for this reason that the idea of testimony forms a point of contact between Evan's essay and that of Richard Bauckham. Bauckham argues that the category of testimony in John's gospel includes a real element of historical reporting in the past. When the Gospel refers to eyewitnesses 'seeing', empirical observation is not all that is implied, nor is it excluded.

In Johannine scholarship 'anti-Judaism' is always an issue under discussion. Under the heading John and 'the Jews' in the fourth section, the essay by Judith Lieu takes issue with Stephen Mortyer's proposals, with the latter proposing a reading of the Gospel in its first-century context that goes further than clearing it of anti-Judaism, in fact offering a substantial answer to the question asked in the title of his essay: 'How might the Fourth Gospel help us to cope with the legacy of Christianity's exclusive claim over against Judaism?' Lieu's discussion, on the other hand, shows how the problem pertaining to the Gospel's use of 'the Jews' cannot be abstracted from other aspects of the Gospel's theology with 
which it is closely connected. Unfortunately, the two essays that follow do not link up with the first two. The essay by Terry Griffith focuses on a particularly puzzling and debated reference to the Jews: 'the Jews who had believed in' Jesus (Jn 8:31). Sigve Tonstad's essay in turn addresses the heart of the Johannine dualism and casts 'the Jews' not in the role of Jesus' principal opponent, but in a subordinate and peripheral role.

The fifth section is more successful in achieving the conversation between the two groups. The Lazarus narrative in particular receives much attention from a variety of methodological and interpretative perspectives. Literary, theological and historical interpretations have been included in this edition. Andrew Lincoln attends to the literary features of the narrative and relates them to the rhetorical intent of the passage, which is to convince readers that Jesus is the Messiah, the Son of God and to have life through faith in him. Marianne Meye Thompson offers a theological interpretation, prefacing it with a concise account of how a theological interpretation differs from any historical approach to the text, even one that describes the theology of the text. Allan Torrance has no endorsement for the assumption that historical work must proceed on a naturalistic, social constructionist epistemic basis. Fundamental to his whole argument is the distinction between God-talk and talk-aboutGod-talk.

In the sixth section (Christology) the only conversation that occurs is that between Martin Hengel and Murray Rae. This conversation revolves around the Prologue. Hengel gives an exposition of the Prologue to the Gospel. He reads the Gospel as a sequential poetic narrative of the revelation of God through his Word. This culminates in the incarnation of the Word as Jesus Christ. Hengel sees the Prologue's climactic verse 14 as a summary of the whole Gospel. Murray Rae too stresses that the Prologue anticipates the central theme of the whole Gospel. His focus differs from that of Hengel. For him it is the theme of creation and the agency of the Word in creation that extends throughout the Gospel as Jesus, by his 'works', continues the divine work of creation, restoring and fulfilling the creation, bestowing abundant life in intimacy with God that constitutes the new creation. Paul Anderson's essay has a different approach to the Christology of John. He displays a characteristic concern of wanting to integrate diachronic and synchronic aspects of the text and considers the Christological and theological tensions in John. Kasper Larsen is on his own when he approaches the Johannine Christology from a narrative perspective, which he refers to as 'narrative docetism.' Using Greimasian narratolog, this represents a fresh approach.

All the essays in the previous sections have implications for constructive Christian theology. The two essays in the last section (Using John in the theological task today) are examples of theological reflection that is rooted in major themes of this Gospel. They actually form starting points for theological construction for today. Unfortunately no dialogue takes place between them. Anastasia Scrutton's concern is with Johannine soteriology as a precedent for a soteriology of salvation as revelation. Jürgen Moltmann's essay is marked by a constant association of the personal with the spatial. The biblical source thereof lies in the Old Testament concept of God's dwelling amongst his people and especially in the Gospel of John.

Two formal aspects about the collection are somewhat bothersome. The first aspect pertains to the inconsistency of Greek and Hebrew words used. In some essays the Greek is transliterated (e.g. in Murray Rae's essay), whilst in others it is not (e.g. in Richard Bauckham's essay). In Martin Hengel's essay the Greek is not transliterated, but the Hebrew is. The second aspect relates to the absence of a subject index.

Notwithstanding the few points of criticism, this volume comprises excellent papers, each one excelling in its own right. Therefore, no theological library should be without this significant resource. The essays certainly keep the debate and enquiry into the Fourth Gospel alive. This book is a must for any student of John's Gospel. The articles cover the pertinent issues surrounding the Fourth Gospel in a thorough manner, yet are written in a readable style. 